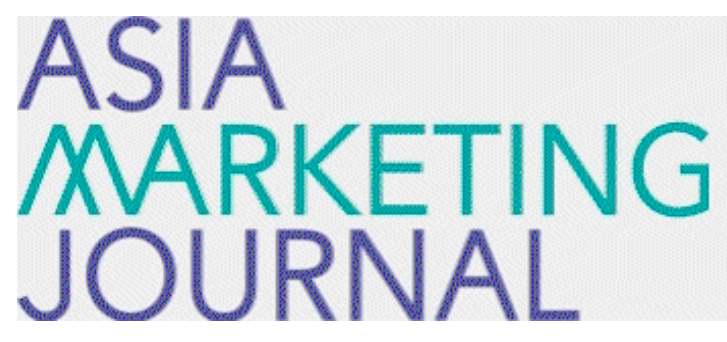

ASIA MARKETING JOURNAL

Volume 11 | Issue 2

Article 4

7-30-2009

\title{
Movie Marketing by Showbox
}

Sang Hoon Kim

Follow this and additional works at: https://amj.kma.re.kr/journal

Part of the Marketing Commons

\section{Recommended Citation}

Kim, Sang Hoon (2009) "Movie Marketing by Showbox," Asia Marketing Journal: Vol. 11 : Iss. 2 , Article 4. Available at: https://doi.org/10.53728/2765-6500.1236

This Article is brought to you for free and open access by Asia Marketing Journal. It has been accepted for inclusion in Asia Marketing Journal by an authorized editor of Asia Marketing Journal. 


\section{Movie Marketing by Showbox: How to Promote Dachimawa Lee*}

Kim, Sang-Hoon**

In the summer of 2008, the movie Dachimawa Lee: Villain, Get on the Express to Hell is waiting for its first release. This movie is based on a short film which was tremendously popular when it was first introduced on the internet in 2000, and the director Ryu Seung Wahn is expecting a mega hit of the movie this summer.

Showbox is one of the leading movie distributors in Korea. After a series of blockbuster hits such as Welcome to Dongmakgol, The Host, and The Chaser, Showbox is now in stagnation. Along with sluggish economy in Korea, most of recent movies distributed by them didn't even reach the breakeven. However, expectation on the upcoming movie, Dachimawa Lee, is higher than ever.

Marketing department of Showbox has to decide what kind of media channel to choose and which marketing strategy to apply. It needs to make a decision about whether to target the so-called mania group or the general public of much bigger size. In this case study, the distinctiveness of the movie marketing and its process will be discussed. Moreover, the marketing strategies for Dachimawa Lee's success will be examined in the Showbox's point of view.

Key words: movie marketing, targeting, positioning, internet marketing

A man is surrounded by villains. They number many, perhaps too many for him to handle alone. They circle him slowly, like a pack of hyenas hunting a wounded prey. Little by little they close in on him, never taking their eyes off his every move. He glares back, never looking away. For a second all is still, all is silent. Abruptly he springs forth into the fray, driven by an unstoppable force. The fight begins.
Pundits in movie industry call this type of scene a 'dachimawalee', a Japanese word meaning a fight scene. In the year 2000, a 35-minutelong short internet movie Dachimawa Lee earned much attention. A hero whose last name is 'Lee' figured in this movie, parodying actions and tone of voices from the movies in the 60's. Dachimawa Lee gained the director,

\footnotetext{
* This case was developed with the support from Brain Korea 21.

** Associate Professor of Marketing, Graduate School of Business, Seoul National University(profkim@snu.ac.kr)
} 
Ryu Seung Wahn, the recognition in his extraordinary action-scene style and he now has successfully solidified his style in other full-length films. The main actor, Lim Won Hee also got the eyes of public, looking the part of characters with colorful facial expressions and ingenious acts of the kinds of action comedy films such as The Mask(1994) starring Jim Carrey and Austin Powers: International Man of Mystery(1997) starring Michael Myers.

Dachimawa Lee has returned in August 2008. This time, it is produced for a full length theatre film with a subheading "Villain, Get on the Express to Hell" (Exhibit 1). The release dates overlap with the peak summer season in Korea. A number of Hollywood movies were just about to premier nearly at the same time. A robot animation, Wall-E (2008) by Pixar, a producer of hit animations such as Finding
Nemo (2003) and Ratatouille (2007), was getting great expectations from students and families. Besides, a new sequel of a superhero movie Batman, The Dark Knight (2008), is drawing a great attention due to its record-breaking first day box office earnings of 18.5 million dollars in the U.S.

Dachimawa Lee features a hero who punishes rascals and spies with a beautiful female partner. He is neither handsome nor attentive but with exaggerated actions and literary style of talking. With the parody scenes of 007 series or cowboy movies, Dachimawa Lee was brining 60's style back into the screen. What kind of marketing strategy should be set up to promote such a movie and to survive fierce competition with competing movies? Showbox, a major film distributor of Korea, is giving an impetus to marketing with the release of Dachimawa Lee

\section{〈Exhibit 1〉 Movie Poster of Dachimawa Lee}
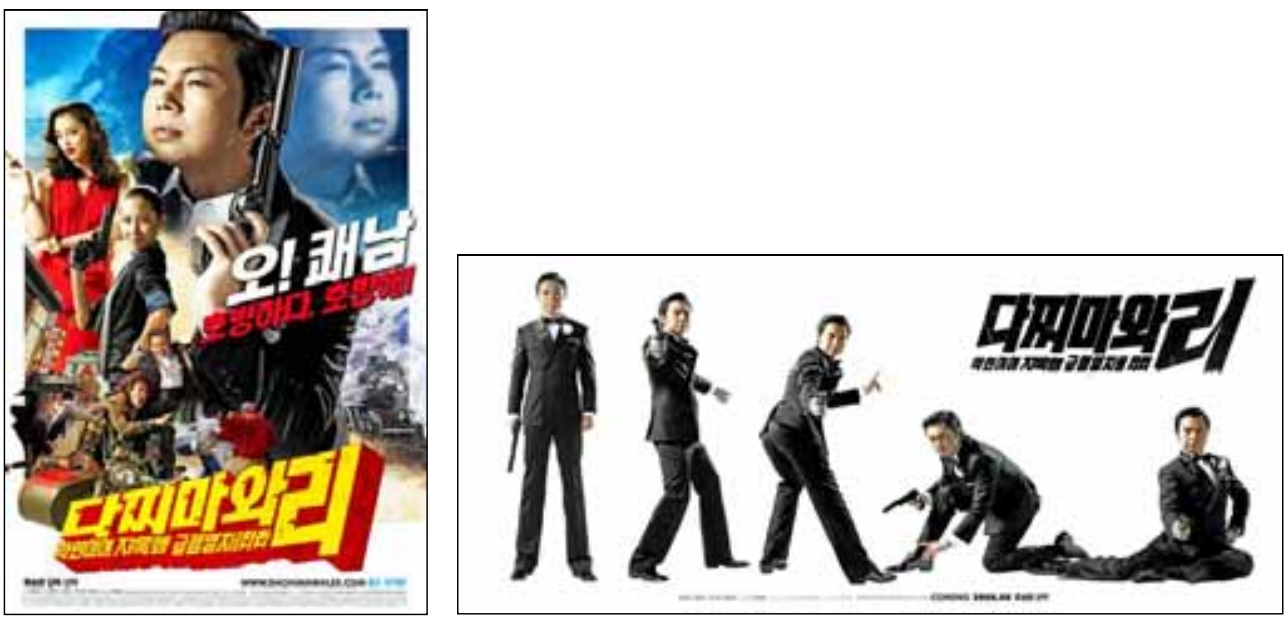

Source: official homepage of Dachimawa Lee, http://www.dachimawalee.com 
around the corner. For example, Showbox has produced a teaser ad for the internet advertising. The actors, actresses, and director are booked on several TV shows to promote the movie.

However, Park Dong Myung, who is in charge of movie marketing of Showbox, is still in agony over the two marketing issues like the following. First, what should be the unique selling proposition (USP) that presumably differentiates Dachimawa Lee from its contenders? Second, which would be the most desirable media to advertise on, TV or internet? Internet would be a natural route to advertise, since the movie was rooted in the internet. However, it seems to be better to shoot a TV ad since the movie will be viewed in the movie theaters this time. Further, a TV ad would reach broader population and bring about an instant effect.

\section{Outline of Korean Movie Industry}

\subsection{Past and Present of Korean Movie Industry}

After reaching the peak in the 1960's with the drama genre, the movie industry of Korea had long been in recession. As direct distribution of Hollywood movies to Korean market became permissible in 1998, Hollywood movies started to enjoy their heyday, which in turn meant difficult time for Korean movie making industry. However, in 1999, the release of a movie named Shiri brought a quick turnaround with nearly six million people seeing the movie. Talents and capital investment began to come back to the industry. Subsequently, a series of box office hits such as The Joint Security Area, Friend, Oldboy, and TaeGukGi: Brotherhood of War ushered in the Korean movie Renaissance era. Around this time, Korean movies started to gain its recognition from the global movie industry. A number of Korean movies have received credit for their high quality in prominent international film festivals. Director Lim Kwon Taek garnered the Best Director's Prize in Cannes Award ${ }^{1)}$ with Chui Hwa Sun in 2002. Director Kim Ki Duk received the same prize in Berlin Film Festival ${ }^{2)}$ with Samaria in 2004, and Oldboy obtained the Best Jury Prize in 2004 Cannes Award. As a result, the export of Korean movies grew so vigorously that it reached beyond 10 million dollars from the movies mentioned above and many others.

Meanwhile, there has been a significant change in movie marketing. Marketing had been of

1) Cannes Award is held every May in Cannes, France. It is famous for its balance between artistic quality and commerciality and is regarded as the Mecca of world movies and celebrated producers.

2) Berlin Film Festival is held every February in Berlin, Germany and it is focused on critiques and directors. It is one of the top 3 world movie festivals with Cannes and Venice Movie Festivals. 
little account for Korean movie productions before the Hollywood movies started direct distribution. At that time, there was a legal restriction that limits the number of days of foreign movie showings per theatre. In 1990s, the restriction was abolished ann 1990era of $\mathrm{mf}$ miplex theaters began. The number of movies and screens increased dreigtically, which left audiences with much more choice than ever before. Eventually, people in iences wi industry began tos inlictithe needs of movie marketing. Domestic distributors attempted tosinitiate fullout marketing activities reapplying the learning $t$ audiencU.S distributors. The influx of capital $t$ audthe big conglomerates and investment companies had accelerated this move.

Since then, multiplex has rapidly replaced old-type movie theaters. As a consequence, increase in the number of screens has resulted in the significant growth of market size in terms of the number of moviegoers. Multiplexes also transformed old, unsanitary, and murky image of movie theaters in old days into pleasant and bright ones of today. Young people who did not have enough places to go for entertainment began heading to the movie theaters.

As multiplexes have remarkably grown in numbers, mainly led by $\mathrm{CGV}^{3)}$ and Megabox ${ }^{4)}$ theatre chains, the box office result of the opening weekend became critical for the success of a movie. Therefore, distributors are putting more and more emphasis on marketing in order to let as many people as possible aware about their movies before its opening. In addition, as wide release screening becomes common, the printing cost has also amplified.

\subsection{Structure of Korean Movie Industry}

Producers, investors, and distributors are the key players in Korean movie industry. The producer acquires scenarios and selects actors, actresses and director. The investment company then evaluates the scenario and analyzes profitability to decide whether to invest or not, and if it does, what type of investment plan it will apply. The distributor is in charge of all the process of delivering the ready-to-beproduced or will-be-produced piece to the theaters and secondary markets. In some cases, one company may invest and distribute at the same time. Normally, distributors are the ones to exercise most influence in achieving the box-office record; their main job is to contact the buyers and have audience purchase the movie on the final step. Movie distributors can

3) CGV was first established by CJ group to be the first multiplex movie theaters in Korea. Its slogan was 'More Impressive than the Movie Itself.'

4) With its slogan being 'Theater More Enjoyable than the Movie Itself,' Megabox now owns more than 10 screens at one location and differentiated its facilities from those of other theaters. This multiplex employed aggressive marketing strategy. It was sold in August 2007 by its parent company Mediaplex. 
make enormous amount of money with one blockbuster movie, while at the same time they are taking huge risks just as much.

The scope and importance of secondary markets such as TV, video, DVD, and internet are becoming greater than the traditional movie theaters in Korean movie industry. It is true that the advent of digital technology has caused negative effects such as illegal reprinting.
However, it is also true that it has provided a new platform for distributing movies.

Looking into movie distribution in Korea until 2007, two major companies of CJ Entertainment and Showbox have been dominating the market. Since CJ Entertainment started to distribute movies from DreamWorks and Paramount Pictures, it became single-handedly the top distributor. After the flood of multitudes of companies into

$\langle$ Exhibit 2〉 History of Mediaplex

\begin{tabular}{|l|l|}
\hline June, 1999 & Established Mediaplex, Inc. Launched into movie industry \\
\hline November, 1999 & Established multiplex theater Megabox. Inc. \\
\hline January, 2002 & Established Showbox, Inc. Launched into distribution and investment industry \\
\hline December, 2003 & Merged with Showbox, Inc. to reinforce distribution and investment department \\
\hline February, 2004 & $\langle$ TaeGukGi: Brotherhood of War〉 Recorded 12million box-office record \\
\hline January, 2005 & $\langle$ Marathon $\rangle$ Recorded 5.16 million audiences \\
\hline August, 2005 & $\langle$ Welcome to Dongmakgol $\rangle$ Recorded 8 million audiences \\
\hline July, 2006 & $\langle$ The Host $\rangle$ Recorded 13million to break the previous box-office record \\
\hline August, 2007 & $\langle$ The War $\rangle$ Recorded 8.41 million audiences \\
\hline February, 2008 & $\langle$ The Chaser Recorded 5 million audiences \\
\hline
\end{tabular}

〈Exhibit 3〉 Hit Movies of Showbox
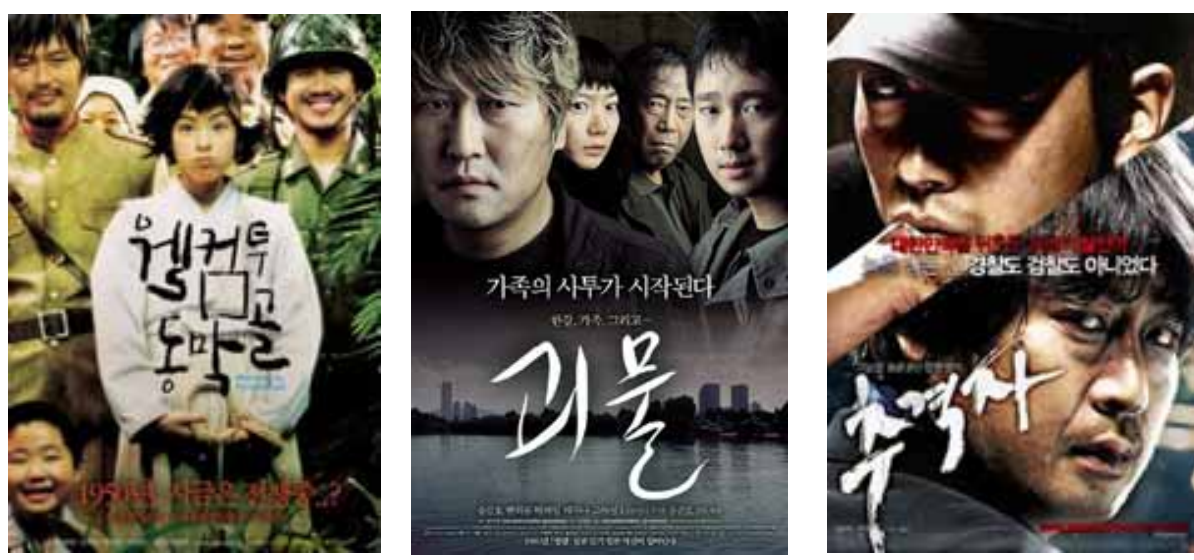

Source: Showbox 
the distribution business, distribution industry is faced with sudden changes. However, market control power of big three distributors including Showbox is still stable. In 2007, they had domestic market share of $77 \%$ and domestic and foreign market share of 53\% (Exhibit 4).

\section{Showbox and its Major Pieces}

\subsection{History and Overall Condition of Showbox}

In January 2002, Mediaplex, one of the subsidiaries of Orion Group, established Showbox

〈Exhibit 4〉 2007 Market share of each film distributor

\begin{tabular}{|c|c|c|c|c|c|}
\hline \multirow[b]{2}{*}{ Rank } & \multirow[b]{2}{*}{ Distributor } & \multicolumn{4}{|c|}{2007} \\
\hline & & $\begin{array}{l}\text { Number } \\
\text { of Films }\end{array}$ & $\begin{array}{c}\text { Number of } \\
\text { Audiences in } \\
\text { Seoul }\end{array}$ & $\begin{array}{l}\text { Percentage of } \\
\text { market share } \\
\text { in Seoul }\end{array}$ & Major Films \\
\hline 1 & CJ Entertainment & 41.5 & $14,636,088$ & $29.7 \%$ & $\begin{array}{c}\text { Transformer, } \\
\text { Voice of A Murder }\end{array}$ \\
\hline 2 & $\begin{array}{l}\text { Showbox, Inc. } \\
\text { Mediaplex }\end{array}$ & 23 & $6,085,384$ & $12.3 \%$ & $\begin{array}{c}\text { The War, Pounds Beauty, } \\
\text { Happiness }\end{array}$ \\
\hline 3 & Warner Brothers Korea & 14 & $5,557,533$ & $11.3 \%$ & $\begin{array}{l}\text { Harry Potter and the Order of } \\
\text { Phoenix, 300, I am Legend }\end{array}$ \\
\hline 4 & $\begin{array}{l}\text { Sony Korea Pictures } \\
\text { Releasing Buena Vista }\end{array}$ & 25 & $4,837,662$ & $9.8 \%$ & $\begin{array}{l}\text { Pirates of the Caribbean: At } \\
\text { World's End, Spiderman 3, } \\
\text { Ratatouille }\end{array}$ \\
\hline 5 & $\begin{array}{l}\text { Lotte Shopping, Inc. } \\
\text { Lotte Entertainment }\end{array}$ & 26 & $4,242,234$ & $8.6 \%$ & $\begin{array}{l}\text { The Golden Compass, A Love, } \\
\text { The Show Must Go On, } \\
\text { Perfume: The Story of a Murder }\end{array}$ \\
\hline 6 & Cinema Service & 15.5 & $3,571,368$ & $7.2 \%$ & $\begin{array}{l}\text { A Good Day to Have an Affair, } \\
\text { Secret Sunshine }\end{array}$ \\
\hline 7 & 20 Century Fox Korea & 18 & $2,778,321$ & $5.6 \%$ & $\begin{array}{c}\text { Die Hard 4, Night at the } \\
\text { Museum }\end{array}$ \\
\hline 8 & UPI Korea & 17 & $1,722,278$ & $3.5 \%$ & Bourne Ultimatum, Break Up \\
\hline 9 & Prime Entertainment & 19 & $1,691,329$ & $3.4 \%$ & $\begin{array}{c}\text { Seven Days, The Nanny Diaries, } \\
\text { Love\&Trouble }\end{array}$ \\
\hline 10 & Studio 2.0 & 11 & $1,117,313$ & $2.3 \%$ & Highway Star \\
\hline & Miscellaneous & 207 & $3,097,927$ & $6.3 \%$ & \\
\hline & Total & 417 & $49,337,416$ & $100,0 \%$ & \\
\hline
\end{tabular}

Source: KOFIC, 2007

* Number of films produced includes carry-overs and re-releasing as well as all released films. Number of films distributed and the number of audiences of co-distributed films are divided into half. 
as an investment and distribution company. To strengthen the investment and distribution function, in December 2003, Mediaplex merged its own independent subsidiary, Showbox, into itself. Besides Showbox, the business domain of Mediaplex covers from production to market release (Exhibit 2). With the advancement of Korean movie industry, Showbox is in the second place in terms of market share from the premiere of more than 20 movies in 2006 and 2007.

Showbox is comprised of 6 main teams; investment planning, production planning, marketing, domestic distribution, foreign distribution and foreign business teams. Investment planning team takes charge of scenarios evaluation, investment decision and contracts with outside investors. Production planning team manages the whole production of a movie, with the support of investment planning team. Distribution team decides when and where to release the movies produced in-house and outside of the company and deals with screen contracts. Marketing strategy developments and executions are naturally conducted by the marketing team.

\subsection{Recent Hit Movies}

\subsubsection{Welcome To Dongmakgol (2005)}

Welcome to Dongmakgol, premiered in the summer of 2005, is based on the Korean War in 1950. It depicts the friendship among South
Korean soldiers, North Korean army soldiers and soldiers from the allied forces who met in a village called Dongmakgol, located deep in a mountain. Touching and funny, this movie overwhelmed all other movies premiered around the same time by attracting 8 million audiences and resulting in a box office smash. It was both the quality of the movie and the nationwide preview screenings that helped spreading substantial amount of positive word of mouths for the movie.

\subsubsection{The Host (2006)}

In 2006, the domestic box-office record was broken by The Host which attracted four million people on its opening day and 14 million in eight days. Winning an award in Cannes Award, The Host, which depicted a monster living in the Han River that runs through Seoul, aroused much curiosity even before its release. Standing Director Bong Jun Ho in the front, The Host triggered people's curiosity by introducing an anonymous monster. The movie's motif is a monster Director Bong claims to have seen when he was young. The technical team collaborated with the CG(computer graphics) crew that had worked on The Lord of The Rings for the enhancement of visual quality and achieved the verisimilitude of the monster. Another strategy used was to keep it perfectly secret on the image of the monster and its identity to arouse inquisitiveness. In 2006, the 
movie was premiered on 71 screens (later up to 116 ) in the U.S. and earned 2.2 million U.S. dollars from the box offices. In September 2008, it was selected among the top 18 Asian movies by CNN.

\subsubsection{The Chaser (2008)}

The Chaser is a thriller movie that deals with a former detective and a kidnapper who abducted a visiting masseuse working at the former detective's massage parlor. The Chaser as well as Welcome to Dongmakgol had low public recognition at first, but both movies earned outstanding evaluation afterwards. Upon its strategy to focus on the movie itself, Showbox spent much effort on making intriguing teasetrailers and widely expose them through internet and TV. Previews for movie industry experts were done in a very large scale. The result was more than satisfactory.

\section{Movie Marketing}

\subsection{Major operations and the process of movie marketing}

Movie marketing process begins well before the production begins and it lasts until sales activities of all other forms of movie products end. That is, movie marketing is to initiate commercialization of a movie and to maximize its market value across all windows. It is essentially a comprehensive communication activity including advertising and PR, through which to let target viewers know about the movie and make them come to the movie theatres. Consequently, awareness building is the key area where greater portion of marketing money is spent than on any other products. Recently, up to $60 \sim 70 \%$ of total budget for one movie is often spent on marketing, which demonstrates the growing importance of marketing.

Different strategies are applied to different movies because of the uniqueness of each movie. It is one of the most important parts of movie marketing to determine which elements of the movie would derive the biggest appeal to people and choose a target based on the genre and the story of it. Needless to say, seasonality and competition are other important factors to be taken into consideration. Decision on the release date is crucial enough to determine success or failure of the movie. Just like any other industry, budgeting, communication and media strategy development and in-market executions should be followed after the key decisions mentioned above are made.

The process of movie making can be divided into three steps $^{5)}$ - pre-production, production,

5) It is sometimes divided into five steps including development and distribution 
and post-production. First of all, pre-production is the stage of forming main concepts of a movie, in which overall plan of the production is discussed. In this step, the proposal, synopsis and the final scenario needed for production are completed. Also, decision on director, staff, and casting is made in this step. The main concept of the movie is the basis of establishing marketing concept. The next step is production process which covers from the crank-in to crank-up and usually follows the form of press conference. Lately, while in the process of filming, companies expose their filming process in other media to arouse curiosity. Post-production process, lastly, includes all the processes of editing, producing, and releasing of a movie. This step requires highly active marketing communications. Normally, "High Concept"6) for the integrated communication activities are determined in this stage and extensive marketing executions are conducted.

Showbox claims that the last 4-week period before the release is the period for direct communication with audiences in approximately 6 months of movie-making time. In this period, key objective of marketing is to increase awareness, preference, and eventually ticket booking rate. Based on the reaction of audiences and box office record in the first week, subsequent marketing plans are decided. Additional copyright is sold to secondary markets including video,
DVD, TV, CATV and IPTV and the prices are decided by the distribution team.

What triggers customers to want to see the movie, or a selling point, takes the place in the center of holistic marketing communication. Showbox, as well, considers selecting High Concept and right communication vehicle the key role of marketing team. When developing High Concept, all surrounding factors, such as actor/ actress, director, genre, story, box-office record, special effect, prize awarded and location should be taken into considerations. Marketing communications are made through advertisement in mass media, PR activities through TV shows and previews, promotional activities, co-marketing and internet.

\subsection{Marketing Cost}

According to statistical yearbook data by KOFIC(Korea Film Council), portion of P\&A (print and advertising) cost in total movie production spending is still high despite its growth rate's being slowed down recently. According to Yearly Status of Production Cost of Korean Movie, average production cost for a movie was 2.55 billion won and P\&A cost was 1.17 billion won, representing $31.5 \%$ of total production cost (Exhibit 5).

Showbox classifies its marketing cost into fixed and variable. Fixed cost commonly applies to most of the movies that includes costs of

6) High Concept: It is a hook which depicts a movie very vividly in one or two sentences to audiences for the maximum attraction. 
labor, viewing of trailers, $\mathrm{POP}^{7)}$ installed in theaters, posters, flyers, and printing. Media spending differs by movie and its target coverage is usually set before the release of a movie but adjusted afterwards, depending on the sales records in the opening week.

According to Showbox, in the case of Korean movies, they spend around 200 million won for TV ads. Due to the nature of movie indust. Dumedia execution is concentrated on the 2 3weeks right before premie TV with higher reaey snd frequency than that of righumer products in foreral. Yet, the level of media spending greatly varies by movie. For example, in 2005, Welcome to Diggmakgoiesllotted 280 million won on TV ad, 17 million on cable TV ad, and another 17 million on onlire ad in total P\&A cost of 1.35 billion won. Also, The Host spent 410 million won on TV ad, 15 million on cable ad, and another 23 million on online ad in total of 1.46 billion won.

〈Exhibit 5〉 Average Yearly Cost of Production of Korean Movies

\begin{tabular}{|c|c|c|c|c|c|c|c|}
\hline \multirow[b]{2}{*}{ Year } & \multicolumn{2}{|c|}{$\begin{array}{l}\text { Practical Production Cost } \\
\text { (A) }\end{array}$} & \multicolumn{2}{|c|}{$\begin{array}{l}\text { Marketing Cost (P\&A) } \\
\text { (B) }\end{array}$} & \multirow{2}{*}{$\begin{array}{c}\text { Total } \\
\text { Production } \\
\text { Cost } \\
(\mathrm{A}+\mathrm{B})\end{array}$} & \multirow[b]{2}{*}{$\begin{array}{l}\text { Number } \\
\text { of Films } \\
\text { Produced }\end{array}$} & \multirow{2}{*}{$\begin{array}{c}\text { Yearly Total } \\
\text { Production } \\
\text { Cost } \\
\text { (Estimated) }\end{array}$} \\
\hline & $\begin{array}{c}\text { Practical } \\
\text { Production } \\
\text { Cost } \\
\text { ( } .1 \text { billion })\end{array}$ & $\begin{array}{l}\text { Percentage } \\
\quad(\%)\end{array}$ & $\begin{array}{c}\text { Marketing } \\
\text { Cost } \\
\text { ( } .1 \text { billion })\end{array}$ & $\begin{array}{l}\text { Percentage } \\
\quad(\%)\end{array}$ & & & \\
\hline 1996 & 9.0 & 90.0 & 1.0 & 10.0 & 10.0 & 65 & 650.0 \\
\hline 1997 & 11.0 & 84.6 & 2.0 & 15.4 & 13.0 & 59 & 767.0 \\
\hline 1998 & 12.0 & 80.0 & 3.0 & 20.0 & 15.0 & 43 & 645.0 \\
\hline 1999 & 14.0 & 73.6 & 5.0 & 26.4 & 19.0 & 49 & 931.0 \\
\hline 2000 & 15.0 & 69.7 & 6.5 & 30.3 & 21.5 & 59 & $1,268.5$ \\
\hline 2001 & 16.2 & 63.5 & 9.3 & 36.5 & 25.5 & 65 & $1,657.5$ \\
\hline 2002 & 24.5 & 65.9 & 12.7 & 34.1 & 37.2 & 78 & $2,901.6$ \\
\hline 2003 & 28.4 & 68.3 & 13.2 & 31.7 & 41.6 & 80 & $3,328.0$ \\
\hline 2004 & 28.0 & 67.3 & 13.6 & 32.7 & 41.6 & 82 & $3,411.2$ \\
\hline 2005 & 27.3 & 68.4 & 12.6 & 31.6 & 39.9 & 87 & $3,471.3$ \\
\hline 2006 & 25.8 & 64.2 & 14.4 & 35.8 & 40.2 & 110 & $4,422.0$ \\
\hline 2007 & 25.5 & 68.5 & 11.7 & 31.5 & 37.2 & 124 & $4,612.8$ \\
\hline
\end{tabular}

Source: KOFIC, 2007

7) $\mathrm{POP}$ (Point of Purchase) refers to the advertising at the point of purchase such as the displays at the movie theaters. 


\section{Rise of Viral Marketing}

Movies are classified as experience goods. When audiences choose what to see, they tend to seek indirect experience and WOM from other people. Moreover, due to the rapid growth in internet industry, influence of on-line WOM is rising. According to the survey conducted by KOFIC in 2007, key considerations for movie selection include story (86.9\%), others' evaluation (70.7\%), actor/ actress (63.5\%). As for the information sources, internet (50.4\%), TV (20.5\%), and acquaintance (17.2\%) were found to be most common. Obviously, the influences of information through personal blogs and homepages are getting more significant to the choice of a movie. Those who have watched a movie share their opinion on the web, themselves being critics, and enrich the information flowing through on-line. As a result, among movie marketers, throwing interesting issues for customers to talk about and letting them to be marketing agents, spreading those information, so called 'viral marketing', became talk-of-town.

Viral marketing is a type of word-of-mouth marketing which is named for its similarity to computer virus. Each individual participates in the delivery process voluntarily to spread information to other people. Viral marketing usually takes forms of UCC, video clips, flash book, e-book, image, and text message. It is also called spread marketing or issue marketing. Spread marketing takes advantage of word-of - mouth and internet rather than newspaper or media to maximize the promotional effect. Issue marketing is a type of marketing that creates continuous issues related to the movie and makes it a social issue to trigger curiosity for box office record of the movie. Despite the major role of on-line WOM, mouth-to-mouth comments from off-line events, such as previews, cannot be dismissed.

The Chaser has achieved remarkable marketing success thanks to issue marketing strategy. Both the leading actor and the supporting actor were relatively not famous and the director was new so that the expectation was quite low in the beginning. In addition, not only did the subject, criminal vs. ordinary man, of the movie seemed cliché, the genre (thriller, action, crime) seemed vague. Nevertheless, Showbox concluded that this was a well-made movie and it decided to put an effort to promote this film. Movie is usually in great demand until February, the end of winter vacation. Thus, it cut down the preview period to release the movie by February $14^{\text {th }}$. Showbox concentrated on teaser preview and movie highlights to represent tension and interest of the movie to make it a center of the attention. In order to boost WOM, preview screenings were held in all screens of one Megabox theatre, and the result was remarkable. The Chaser, in spite of soft progress in the beginning, recorded 5 million accumulated

8) UCC: User Created Contents 
audiences in the end.

Welcome to Dongmakgol also utilized preview screenings to spread information about the movie. Like the Chaser, the actors and the actresses were not attractive in a sense to draw people's interest whereas the movie was highly entertaining. Showbox marketing team heavily advertised preview itself on and offline and provided seats for over 23 thousand people through the events. It was ignited by the belief that previewers were the ones with the most interest in movies and potential subjects to spread WOM. If they were satisfied with the movie, they would make big WOM. Dongmakgol attracted 8 million audiences and the movie put the heroine, Kang Hye Jung, on stardom over a night.

\section{Marketing Strategy for Dachimawa Lee}

Showbox usually conducts viewer surveys as well as internal evaluation to determine the marketing focus of upcoming movies. It extracts unique and friendly images from the scenario, the director, and the actors, and unifies them to make trailers or posters. Once main concept is decided, next job is to identify what would be the most effective media and what would trigger the spread of 'the virus' to obtain the target's awareness and preference. Dachimawa Lee also had FGI (Focus Group Interview) to diagnose attitudes towards the internet version of the short film, the director, and the actor/ actress. They reached a conclusion to keep the overall tone of the short film with the sentiment of a $\mathrm{B}$ rank movie.

The background of Dachimawa Lee, to be released in theaters in 2008, is 1940's. Japanese Emperor's Army is frantically looking for a list of Korean Army for Independence, hidden in a national treasure. Meanwhile, a female agent Keum Yon Ja (Kong Hyo Jin) of Army for Independence disappears in a mission. The best secret weapon of Army for Independence, Dachimawa Lee (Lim Won Hee) and the glamorous female agent, Mary (Park Sih Yeon) are sent for the mission instead. In the process of searching for the national treasure, Dachimawa Lee engages in a fight with Japanese armies and a villain, Borderline Wild Cat (Ryu Seung Hwan).

Gems of the movie are dazzling 60-70's like homage ${ }^{9)}$ actions, the talk delivered in tone of 60 's film interpreter, and out-of-date postrecording ${ }^{10)}$ techniques. This movie parodies all kinds of spy movies to induce intentional silliness. Audaciously and brazenly, the scenes shot in Korea are turned into that of Alps. Mismatching exaggerated actions and sincere speech arouses

9) Quoting few lines and/ or scenes from other movies to honor them

10) Recording lines, background music, and sound effects accordingly after the shooting. 
〈Exhibit 6〉 Expenditure on Media PR of Showbox (unit: 1000won)

\begin{tabular}{|c|r|r|}
\hline Channel & Welcome to Dongmakgol & The Host \\
\hline Newspaper & 449,100 & 472,200 \\
\hline TV Advertisement & 286,279 & 412,387 \\
\hline CATV Advertisement & 173,000 & 155,000 \\
\hline On-line Advertisement & 170,000 & 228,000 \\
\hline Radio & 20,701 & - \\
\hline Magazine & 51,425 & 41,500 \\
\hline Bus & 112,500 & 103,172 \\
\hline Subway & 44,700 & 11,540 \\
\hline Theater Advertisement & 6,000 & 20,000 \\
\hline Neon Sign & 8,000 & 15,000 \\
\hline Posters on Street & - & 7,920 \\
\hline \hline Total & $1,321,705$ & $1,466,719$ \\
\hline
\end{tabular}

Source: Showbox

big laughters. Director Ryu Seung Wahn debuted in movie industry with Die Bad and has built up his career with unique action films such as Mission Arahan and Crying Fist. He is supported by young audiences and he chose to remake a short internet version film Dachimawa Lee that recorded 1.25 million hits on internet into his sixth full-length film.

Main stratum of audience of this full-length film will be young generation users who remember the internet-version of 2000 film. Showbox assigns average of 150-350 million won per movie to online marketing, with the steady increase in its percentage of total costs. However, it is getting more and more difficult to find optimum level in splitting the budget between TV and online ads. To air on terrestrial TV, it costs more than any other media that the company puts TV ads on-air only if there is an issue in awareness level for the movie to be released soon (Exhibit 6). Internet version of 2000 Dachimawa Lee has already formed favorable impression and has obtained positive responses from online viewers as for now, weeks ahead of premiere.

Marketing team-leader, Park Dong Myung is racking his brain on the media and PR strategy for Dachimawa Lee; 'preview and internet' or 'TV ads'. Given its origin from the internetbased film and the growing influence of on-line marketing, should they focus on mania group to expect viral marketing effect? Or, as the movie is made for theaters now, should they target wider range of people and spend big money on TV? What on earth will be the best choice to get Dachimawa Lee on the Express to success?

〈논문 접수일: 2009. 04. 11〉 〈게재 확정일: 2009. 05. 21〉 


\section{$\langle$ Teaching Note〉}

\section{Purpose and Use}

In this case study, process of movie marketing and related issues will be discussed based on the process used to form the marketing strategy for Dachimawa Lee. This will facilitate the understanding of communication strategy using media and other types of marketing strategies.

This case can be used for studying marketing strategy issues listed below:

- Difference between the movie marketing and general consumer marketing

- Overall process and operations of movie marketing

- Deriving STP and a High concept in movie marketing

- Various media strategies for movie marketing

- Understanding consumer behavior in the context of moviegoing

\section{Study Questions}

1. Summarize the production and marketing process of Showbox, compare and contrast the difference between the movie marketing and the consumer products marketing.

2. Showbox marketing team is to decide which market segment to target; mania group or general public. Consider the two groups and discuss what kind of USP would be appropriate for each of them. Then, propose the "High concept" of the movie in one sentence for each group.

3. Based on what has been discussed in the questions above, choose a target and propose an adequate marketing strategy for Dachimawa Lee. Which would be more appropriate advertising channel for the movie, TV or Internet?

\section{Analysis}

1. Summarize the production and marketing process of Showbox, compare and contrast the difference between the movie marketing and the consumer products marketing. 
The process of movie-making can be divided into three steps - pre-production, production and post-production.

1) In the process of pre-production, overall plan of the production is discussed and the proposal, synopsis and the final scenario are completed. Also, decision on director, staff, and casting is made in this step. This step is the process of establishing the main concept of the movie which will become the basis of movie marketing.

2) Production process includes all activities of filming from the crank-in to crank-up and is usually followed by press conference.

3) Post-production process includes all the activities of editing, producing, and releasing of a movie via a distribution company. This step requires the most active marketing communication as it approaches the premiere of the movie.

Key differences between consumer products marketing and movie marketing are summarized in the table below:

\begin{tabular}{|c|c|c|}
\hline & Consumer Products Marketing & Movie Marketing \\
\hline Product Type & Consumer packaged goods, Durables & Experience goods \\
\hline Mode of Production & Mass production of identical products & Each product is unique \\
\hline Product Life Span & Varies from months to years & $\begin{array}{l}\text { Very Short (may become longer in case of } \\
\text { additional copyrights) }\end{array}$ \\
\hline $\begin{array}{l}\text { Characteristics of } \\
\text { Marketing Activity }\end{array}$ & $\begin{array}{l}\text { - Segmentation and targeting, possibly } \\
\text { multiple targets } \\
\text { - } 4 \mathrm{P} \text { marketing mix decisions } \\
\text { - mass promotion (TV ads, sales } \\
\text { promotions are effective) }\end{array}$ & $\begin{array}{l}\text { - Intensive marketing efforts for about } 4 \\
\text { weeks before launch } \\
\text { - Continuously becomes costly because it } \\
\text { has primary focus on advertising } \\
\text { - previews and events are effective }\end{array}$ \\
\hline Market Survey & $\begin{array}{l}\text { - Conduct formal consumer surveys such } \\
\text { as FGI, CLT. } \\
\text { - Steady tracking of sales figures, } \\
\text { market share, and advertising impact }\end{array}$ & $\begin{array}{l}\text { - Main concept is decided and fixed early } \\
\text { in the pre-production step } \\
\text { - Selling points are decided at launching } \\
\text { - Title recognition, consumer preference, } \\
\text { advance ticket sales rate are estimated }\end{array}$ \\
\hline
\end{tabular}

Detailed marketing activities of movie marketing include:

\section{- Advertising}

Unlike other products, movies have relatively short life span so that it relies on short-term 
advertising campaign. The key merit of media advertising is accessibility to the public in a short period of time. Usual advertising media used for the advertisement are TV, CATV, radio broadcast, newspaper, poster, leaflet, free newspaper, and many other printings. Public transportation advertisement, neon sign, banner, cell-phone, and internet banner could also be used as advertising media.

\section{- PR}

Usually, PR takes place in the forms of an advertorial or an event. The most generally used form is a press interview of the director or the actors/actresses and their appearances on the TV shows. Information released by the press earns high reliability and credibility due to its objectivity. Recently, it became customary for actors to appear on the TV programs when it is close to the release.

\section{- Promotion}

Promotion is an effort used to lay a foundation for the box-office success. Granting certain privileges to potential viewers is called direct promotion. Indirect promotion is to inform the public about the movie through merchandizing and sponsoring. Tie-in, which is a type of merchandizing, is a co-promotion strategy that features popular characters in the movie on merchandized item for sales, sanctioned in contract. PPL (product placement) is another form of sponsorship.

- Word-of-mouth

Actively managing word-of-mouth on the movie, a distribution company tries to spread favorable response to the movie by the public. Once the movie is released, the company tends to rely more on the word-of-mouth than media advertising. The main sources of the word-of-mouth campaign are the internet and the previews.

2. Showbox marketing team is to decide which market segment to target; mania group or general public. Consider the two groups and discuss what kind of USP would be appropriate for each of them. Then, propose the "High concept" of the movie in one sentence for each group. 


\subsection{Explain what High Concept is about}

The term "High Concept" was first introduced by Michael Eisner, ex-chairman of Walt Disney. He emphasized that the main concept of a film should be explained in just one or two simple

phrases. Generally, High Concept is taken place with simple and clear message that depicts the story along with a celebrity or the director of the movie and the arrangement of slogan, identity and image that seem highly appropriate and profitable.

\subsection{Compare and contrast the movies that will be competing with Dachimawa Lee and derive possible USPs for the main target.}

- The competition among domestic and foreign movies will be severe in summer because teenagers and college students will bring special demand at that time. Korean blockbuster The Good The Bad The Weird (Director Kim Ji Hoon) is enjoying a box office hit since its release in last July, attracting more than 5 million audiences. Dark Knight and Wall-E, which were produced with large amount of Hollywood capital, will also be released around the same time. Compared by them, the scale, action, and scenery of Dachimawa Lee are not strong enough to differentiate it from others.

In what form should it appeal to the public then? The actors from the original internet version of Dachimawa Lee were featured in this movie. Because of their low recognition and popularity and the artistry and quality of the movie itself, it seems difficult to earn great praise. They are expecting to stir the nostalgia of $60^{\circ}$ s and $70^{\circ}$ s by Lim Won Hee's comic acts with absence of facial expression and his old speech style. With the subtitle Villain, Get on the Express to Hell, it is targeting the niche market for people who wants to enjoy the movie without load of thinking. Not only appealing its silliness and simplicity, but also appealing clean and neat action scenes by Director Ryu, the movie could position well as a well-made B rank movie.

Issues Considered in deriving USPs of Dachimawa Lee

- Emphasize on non-mainstream style, new B rank movie directed by Director Ryu

- Emphasize the characteristics of parody genre adopting the spoof genre.

- Penetrating the blind spot of blockbusters with comical elements of Korean style 
2.3 Derive USP with consideration of the property of each target and analyze the High Concept which Showbox can apply to promote the movie "Dachimawa Lee".

\begin{tabular}{|c|c|c|c|}
\hline \multicolumn{2}{|c|}{ Target } & USP & High Concept \\
\hline \multirow[t]{3}{*}{ Mania } & $\begin{array}{l}\text { Fans of Director } \\
\text { Ryu }\end{array}$ & $\begin{array}{l}\text { The film by } \\
\text { Non-mainstream director } \\
\text { Ryu }\end{array}$ & $\begin{array}{l}\text { - Director Ryu's own style of comedy } \\
\text { action } \\
\text { - The sixth full film by Ryu }\end{array}$ \\
\hline & $\begin{array}{l}\text { Internet-based } \\
\text { movie manias }\end{array}$ & $\begin{array}{l}\text { theater version of original } \\
\text { internet movie }\end{array}$ & $\begin{array}{l}\text { - Return of vigor and valor Dachimawa } \\
\text { Lee } \\
\text { - Majestic B rank action, return of } \\
\text { Dachimawa Lee }\end{array}$ \\
\hline & $\begin{array}{l}\text { Manias of parody } \\
\text { genre }\end{array}$ & Spoof genre & $\begin{array}{l}\text { - Korean version of Austin Powers, new } \\
\text { movie style }\end{array}$ \\
\hline \multirow[t]{2}{*}{$\begin{array}{l}\text { Mass (General } \\
\text { Public) }\end{array}$} & $\begin{array}{l}\text { Audiences of easy } \\
\text { comedy genre }\end{array}$ & $\begin{array}{l}\text { Silliness } \\
\text { Art of excessiveness }\end{array}$ & $\begin{array}{l}\text { - Counter attack of vigor and valor } \\
\text { Dachimawa Lee! } \\
\text { - Get on the Express to laughter, funniest } \\
\text { quotes ever } \\
\text { - Art of shameless, deceptive B rank } \\
\text { movie with A rank action } \\
\text {-Silly, low-class action comedy }\end{array}$ \\
\hline & $\begin{array}{l}\text { General public with } \\
\text { not much interest } \\
\text { in movie itself }\end{array}$ & Excellent acting & $\begin{array}{l}\text { - Time of vigor and valor man, Feel the } \\
\text { charm of Dachimawa, Lim Won Hee! } \\
\text { - Sexy Bond girl acted by Park Sih Yeon. }\end{array}$ \\
\hline
\end{tabular}

3. Based on what has been discussed in the questions above, choose a target and propose an adequate marketing strategy for Dachimawa Lee. Which would be more appropriate advertising channel for the movie, TV or Internet?

\subsection{Targeting}

A strategy depends on the target. The type of media for marketing should be decided based on whether to approach the general public with universality or to focus on the manias with insensitivity. 


\begin{tabular}{|l|l|l|}
\hline & \multicolumn{1}{|c|}{ Targeting Mania } & \multicolumn{1}{|c|}{ Targeting Mass } \\
\hline Advantage & $\begin{array}{l}\text { Easy to focus and rely on certain mania } \\
\text { group for word-of-mouth strategy } \\
\text { May expect effective relay of their words } \\
\text { to general public }\end{array}$ & $\begin{array}{l}\text { Possibility of attracting more people to } \\
\text { theater by informing general public about } \\
\text { the movie. }\end{array}$ \\
\hline Disadvantage & $\begin{array}{l}\text { Low expectation on big hit } \\
\text { In many cases, it is not preferred by } \\
\text { general public }\end{array}$ & $\begin{array}{l}\text { When lacking universality and distinctive } \\
\text { style, it is easily ignored. }\end{array}$ \\
\hline Main Channel & Internet & TV advertisement \\
\hline
\end{tabular}

\subsection{Issues to be considered when establishing strategy on marketing using media.}

- Theater version of Dachimawa Lee that swept internet in 2000

- Internet generation is the "proven" well-suited major target of the movie

- Not enough elements to appeal to general public, especially middle and old aged audiences

- Considering all of these, it seems more appropriate to promote the movie on the internet. Throwing events and online PR will also be effective to bring them to the theatres.

\section{What Happened}

- Before the release, when the teaser poster was distributed to the public, it started to get spotlights among netizens and became a source of secondary parody. Warming up the atmosphere with trailer that cleverly parodied 007 series and high-quality music video featured by Leessang and Epic High(Top Korean Singers)and narrated by Lim Won Hee, Showbox expected the same size of response to 2000 internet version.

- Nonetheless, it attracted only 300 thousand in the first week of release and barely exceeded 600 thousand accumulated audiences in the first month. It was not even close to their break-even point of 1.5 million. The result was disastrous.

- Although Showbox expected as much interest as it earned with 2000 internet version which recorded 1.25 million hits, it failed to bring the internet-based mania group to theaters and bombed in box-office record. 


\section{Lessons Learned}

- Strategies used such as releasing teaser poster on the web and distinctive music video were effective to attract the main target of the movie, i.e., mania group, and there were significant indication of interest and response in return. However, when Showbox changed their strategy to rely more on mass market approach, its media strategy strayed away from its core target.

- Consistent advancement in media strategy was one of the key factors, but it chose to have the director and the actors/ actresses go to the TV shows--turning to mass strategy. Thus, the marketing strategy lost focus and momentum.

- Inconsistent and fluctuating marketing strategy made mania groups who were supposed to carry on positive word-of-mouth turn their backs on the movie. It not only lost its core audiences, but failed to earn public recognition.

- Movie review magazines evaluated Dachimawa Lee as homage to classic that made the movie seem quite difficult to interpret. This kind of review created negative effect to general public with little or no knowledge on this movie, making the movie seem difficult and was eventually ignored. 